\title{
Consumer Perceptions of Nonprofit Enterprise: Reply
}

\author{
Henry B. Hansmann $\nmid$
}

Professor Permut has conducted an empirical study of consumer attitudes toward nonprofit organizations that, though not without some problems in its design and execution, provides surprisingly strong support for the theories advanced in my article, The Role of Nonprofit Enterprise. ${ }^{1}$ Oddly, Professor Permut strains hard in his Comment to interpret his findings as inconsistent with my theories. In the process, Professor Permut occasionally gives a strange reading to my original article. I shall respond by saying say a few words to clarify both the interpretation of my article and the significance of Professor Permut's survey.

In my article, I divide nonprofits loosely into two broad categories: donative nonprofits, which derive a substantial portion of their income from grants or donations, and commercial nonprofits, which derive most or all of their income by selling their services directly to consumers. As I note, "[d]onative nonprofits provide the simplest and clearest applications of the contract-failure theory" that is set forth in the article, ${ }^{2}$ and much of the article is devoted to an analysis of the sources and forms of contract failure that affect services provided by donative nonprofits. In a footnote, Professor Permut acknowledges the strength of the contract failure theory as it applies to donative nonprofits, and states that his comments are limited to the application of my theories to commercial nonprofits. ${ }^{3}$ Indeed, Professor Permut's comments generally focus even more narrowly on several particular types of commercial nonprofits, notably nursing homes and summer camps.

As I was at pains to emphasize in my article, contract failure is a much weaker phenomenon in the case of those services typically provided by commercial nonprofits than it is in the case of those services typically pro-

$\dagger$ Associate Professor of Law and Public Policy, University of Pennsylvania.

1. Hansmann, The Role of Nonprofit Enterprise, 89 YALE L.J. 835 (1980) [hereinafter cited without cross-reference as Rolej.

2. Role at 846 .

3. Permut, Consumer Perceptions of Nonprofit Enterprise: A Comment on Hansmann, 90 Yale L.J. 1623, 1624, n.4 (1981) [hereinafter cited without cross-reference as Consumer Perceptions]. 
vided by donative nonprofits. ${ }^{4}$ When an individual is purchasing a service for his personal consumption, as is the case with most services provided by commercial nonprofits, he is in a much better position to control the quality of service rendered to him than he generally is when patronizing a donative nonprofit. Consequently, the services provided by commercial nonprofits are also typically provided by competing for-profit firms. Indeed, for-profit firms are the dominant form of supplier in most industries in which commercial nonprofits are found.

Residential nursing care, upon which Professor Permut focuses heavily, is a good example. Roughly five out of every six private nursing homes are proprietary. ${ }^{5}$ Moreover, of the one-sixth that are nonprofit, some have presumably taken this form because they are donatively financed (and hence are responding primarily to contract failure problems felt by their donors rather than by their paying customers). Obviously, then, most nursing home customers do not feel that problems of contract failure are so severe that they are willing to trust only a nonprofit firm. Potential nursing home customers presumably compare those aspects of price and service that they are able to observe in different homes, and rely primarily upon such comparisons in choosing which home to patronize. The fact that a home is nonprofit, rather than for-profit, is likely to be important only if most observable dimensions of price and service seem roughly comparable among competing homes, or if the customer is too aged, infirm, inexperienced, or insecure to trust his own judgment in selecting a home. Presumably much the same is true in the case of other types of institutions discussed by Professor Permut, such as summer camps and day care centers, which are sometimes formed as commercial nonprofits, but are generally organized as proprietary firms. ${ }^{6}$

In short, contrary to the reading that Professor Permut seems to give my article, I do not claim that there is massive contract failure in such businesses as residential nursing care or summer camps and that as a result consumers are concerned only, or even primarily, with the fact that a potential supplier is for-profit or nonprofit. ${ }^{7}$ On the other hand, I do not

4. Role at $863,871-72$.

5. Role at 863 n.81.

6. As of $1977,73 \%$ of all sporting and recreational camps and $57 \%$ of day care centers were forprofit. U.S. DEPARTMENT OF COMMERCE, BUREAU OF THE CENSUS, 1977 CENSUS OF SERVICE INDUSTRIES: OTHER SERVICE INDUSTRIES 53-1 to -3, 53-12 (1981) (SC77-A-53); U.S. DEPARTMENT OF COMMERCE, BUREAU OF THE CENSUS, UNITED STATES REPORT (SELECTED SERVICE INDUSTRIES) (1981) (SC77-A-52).

Moreover, as observed in my original article, the operative difference in the case of small-scale enterprises such as summer camps between a for-profit and a nominally nonprofit firm is probably not very significant from the point of view of either the customers or the entrepreneurs, and market forces would not tend to select strongly for one form over the other. See Role at 870-71.

7. It is apparently this misreading that leads Professor Permut to make the strange assertion that the fact that most nursing homes and day care centers are proprietary is somehow a refutation of the 
want to suggest that contract failure counts for nothing in such industries. Nonprofit firms have a substantial, though by no means dominant, presence in such complex personal service industries as residential nursing care, day care, and children's summer camps. At the same time, nonprofit firms are virtually never to be found in the production and distribution of cucumbers and machine screws. The obvious explanation for this pattern seems to be that while contract failure is not overwhelming in the personal service industries, it is a far more serious problem there than in the market for cucumbers and machine screws, in which competition works reasonably well to protect the interests of consumers. (We should also keep in mind that supply-side factors as well as demand-side factors govern the extent of nonprofit development in any given industry. ${ }^{8}$ )

\section{II}

Let us turn now to Professor Permut's survey responses to see how well they tally with this view of commercial nonprofits.

Professor Permut seems to argue that contract failure cannot be important in explaining the presence of commercial nonprofits in industries such as residential nursing care and summer camps for children because his survey responses indicate that consumers are generally unaware of whether a particular institution that they are considering patronizing is nonprofit or for-profit, and that even when consumers knowingly face a choice between nonprofit and for-profit providers of a service, they do not in fact consider the nonprofit firms to have any important fiduciary qualities not to be found in the for-profit firms. In fact, however, Professor Permut's survey does not seem to me to establish the first point, and it strongly supports a conclusion opposite to the second.

His survey indicates that many residents of the New Haven area are confused or mistaken about the legal form of particular New Haven organizations. As Professor Permut concedes, however, most of the people contacted in his telephone poll probably have never patronized most of the

contract failure theory. See Consumer Preferences at 1630.

8. See Role at 897 . I have recently explored some of these supply-side factors-particularly legal constraints-at length elsewhere. Hansmann, Reforming Nonprofit Corporation Law, 129 U. PA. L. RtV. 497 (1981).

In footnote 24 and the accompanying text, Professor Permut discusses some issues concerning the motivation and performance of those who work for nonprofits. The first paragraph of that footnote seems to reflect a misreading, or a non-reading, of the appendix to my article. The second paragraph focuses on the likely fact that nonprofits are not always managed as efficiently as for-profit firms. I discuss this latter issue at some length in my article, and, in contrast to the view imputed to me in the last sentence of footnote 24, I state explicitly (and repeatedly) in the article that such managerial inefficiencies (as well as other inefficiencies inherent in the nonprofit form) must be balanced against the fiduciary advantages attendant to the nondistribution constraint in evaluating the effectiveness of nonprofits in meeting consumers' needs in providing any particular service. 
institutions included in the survey, or, when they have patronized one of these institutions, have not themselves been responsible for choosing which institution to patronize, and in particular whether to patronize a nonprofit or for-profit firm. For example, the nonprofit status of the New Haven Symphony is presumably of importance only to its donors, yet it is unlikely that the respondents to Professor Permut's poll included many, if any, donors.' Similarly, although many of the individuals in the poll may have been covered by Blue Cross or Blue Shield, or by one of the competitors of these organizations, it was probably their (or their spouse's) employer, and not they, who decided which health plan to patronize. Consequently, we do not learn much when we find that many people in this sample are unclear as to whether such organizations are nonprofit. ${ }^{10}$

The more important question is whether those people who decide whether to patronize a given institution are aware of its for-profit or its nonprofit status. The results of a survey of consumer attitudes toward day care that was conducted by Professor James Newton provide more direct evidence on this issue than do Professor Permut's results. Professor Newton's survey suggests that most individuals who have actually patronized day care centers are well aware of whether they chose a nonprofit or a for-profit provider. ${ }^{11}$

\section{III}

What then does Professor Permut's poll tell us about patrons' (or, rather, more or less randomly selected telephone interviewees') attitudes

9. The typical respondent to the survey was female, less than 35 years old, and had less than a high school education. Consumer Preferences at 1626 n.9. See generally Role at 854-59 (discussing role of nonprofit firms in performing arts).

Given that most respondents to Professor Permut's poll not only have presumably never donated to the New Haven Symphony, but have probably never even attended one of its performances, and given that most musical and theatrical performances attended by the average respondent to the poll are probably produced by for-profit organizations, the pattern of responses in the poll concerning the Symphony seems quite understandable.

10. The only thing that I find particularly surprising-indeed amusing-in the responses concerning the 11 organizations covered by the survey is the fact that a clear majority of these New Haven area residents thought Yale University is for-profit. As discussed in my article, Role at 859-62, the nonprofit status of a university is primarily of concern to its donors, and it is unlikely that the respondents to this survey included many actual or potential Yale donors. Consequently, these reponses, like those for the other organizations, do not tell us much either way about the contract failure theory of nonprofits. Assuming, however, that these responses are not facetious, they do tell us something about town-gown relationships; apparently New Haven residents do not look upon Yale very, as it were, charitably.

11. Professor Newton, in a telephone survey, asked 119 randomly selected users of child care services whether the service they patronized was (1) nonprofit church-affiliated, (2) nonprofit and not church affiliated, (3) for-profit, (4) cooperative, or (5) governmental. Only $8 \%$ said they did not know. Of course, some fraction of the respondents may have been mistaken concerning the category to which they assigned the organization they patronized; it is not possible to tell from the survey how large that fraction is. J. Newton, Preliminary Data from Child Care Decision Making Survey (Aug. 1980) (Program On Non-Profit Organizations, Yale University) (on file with Yale Law Journal). 
toward nonprofit versus for-profit firms? It is hard to draw clear conclusions, because we are told very little about the overall structure of the poll and the manner in which it was presented. We are not even told whether the respondents were asked to choose from among a given list of responses to each question, or whether they were allowed to respond freely-with Professor Permut subsequently interpreting and aggregating the responses to obtain the categories of responses he reports. Moreover, the responses to some questions are reported only in part. ${ }^{12}$ Nevertheless, the results reported by Professor Permut are at least suggestive.

In the text of his article, Professor Permut chooses to present only the percentage of interviewees who gave responses that Professor Permut considers inconsistent with the theories advanced in my article. A glance at the full pattern of responses, as reported in Professor Permut's footnotes, tells a rather different story. For example, when asked "Do you feel that a 'nonprofit' organization will treat you more fairly and honestly than a 'for-profit' organization," forty-two percent of the respondents replied "yes," only twelve percent replied "no," and forty-four percent replied "don't know/not necessarily." Moreover, "[f]or those who answered 'yes" to the original question, a frequent reason given was that nonprofits 'have nothing to gain or lose." "13 These responses, and the similar responses to the two other general questions of the same sort, ${ }^{14}$ seem to me to be highly consistent with, and to give strong support to, the contract failure theory of nonprofits offered in my article. (Note, moreover, that those responding "not necessarily" may well include many who feel that nonprofits are generally, though perhaps not always, more to be trusted than for-profit firms. I myself would probably have chosen the "not necessarily" response to this question.)

When asked, with respect to nursing homes in particular, whether they

12. The day care survey undertaken by James Newton, see J. Newton, supra note 11, which focuses on the same type of issues as does Professor Permut's survey, is more detailed, covers a somewhat broader range of issues, and appears more sophisticated in its design and execution. Although at present only a preliminary tabulation and analysis of Professor Newton's results is available, they suggest in general that in choosing a day care center parents are sensitive to the nonprofit/for-profit distinction; they tend to place somewhat greater trust in nonprofit providers, but are primarily guided by observable differences in price and quality. These results seem broadly consistent both with Professor Permut's results, as discussed below, and with the views set forth in my article.

Professor Newton's survey (which I will leave to him to report in detail), unlike Professor Permut's, seeks to determine how difficult consumers feel it is to judge the quality of service they receive from day care centers-that is, how much "contract failure" consumers perceive. Professor Newton found that "a majority $(55 \%)$ of respondents who expressed an opinion considered it difficult for parents to judge the quality of child care received by their children." J. Newton, supra note 11, at 2. This is to be contrasted with Professor Permut's strong and largely unsupported inference that "consumers do not believe that contract failure exists in the selection of a nursing home or summer camp." Consumer Preferences at 1630.

13. Consumer Perceptions at 1628 n.13.

14. See id. 
would "care whether the home were labeled 'nonprofit' as opposed to 'forprofit," " twenty-eight percent responded affirmatively and fifty-five percent responded negatively. ${ }^{15}$ We are not told whether the twenty-eight percent who responded affirmatively would view the nonprofit designation as a positive or a negative consideration; some indication can be derived, however, from the responses Professor Permut reports for a similar question about summer camps, in which three-fourths of those who thought the nonprofit/for-profit designation important preferred the nonprofit form. ${ }^{16}$ These responses are quite consistent with the fact that only about fifteen percent of nursing home patients actually choose (or have chosen for them) nonprofit homes, and reflect, as discussed above (and in my original article), a relatively low but not insignificant degree of contract failure in this industry. Quite predictably-and quite consistently with everything that is said in my article-Professor Permut finds that many individuals feel that observable aspects of quality of care are the most important considerations in choosing a nursing home. Questions about summer camps produced similar responses, except that a somewhat larger percentage evidently felt that the nonprofit form was important. ${ }^{17}$

\section{IV}

Although I disagree at various points with the interpretation that Professor Permut has given both to my article and to his survey results, I am grateful to him for his effort to test empirically the validity of the theories set forth in my article. His survey is one of the few systematic sources of information now available on consumer attitudes toward nonprofits. I quite agree with Professor Permut, moreover, that there is a need for more extensive empirical work on consumer demand for the services of nonprofits ${ }^{18}$ and on the degree to which the nonprofit form, whatever consumers may think of it, actually serves as an effective response to contract failure.

15. Id. at 1629 n. 14 .

16. Id.

17. Id.

18. In this connection, I look forward in particular to full publication of the results of Professor Newton's survey. See J. Newton, supra note 11; note 12 supra. 